\title{
INTEGRASI ISLAM DAN SAINS DALAM KURIKULUM PROGRAM STUDI PENDIDIKAN GURU MI BERBASIS KKNI
}

\author{
Fauzan \\ FITK UIN Syarif Hidayatullah Jakarta \\ Email: fauzan@uinjkt.ac.id
}

Naskah diterima : 7 Desember 2016, direvisi : 29 Desember 2016, disetujui : 5 Januari 2017

\begin{abstract}
Perubahan merupakan tanda dalam kehidupan yang selalu berlangsung secara tetap. Apabila tidak terjadi perubahan, maka akan terjadi kemandegan dan kehidupan tidak akan berkembang sesuai perkembangan zamannnya. Perubahan IAIN menjadi UIN merupakan upaya melakukan proses perubahan kurikulum, cara, metodologi, situasai dan kondisi yang tradisional (ortodox) ke arah yang lebih rasional, profesional dan sesuai perkembangan ilmu pengetahuan dan teknologi dengan tidak meninggalkan ciri "keislaman" dan "ke-Indonesiaan" sebagai penciri mutlak keberadaan lembaga pendidikan tersebut. Integrasi Islam dan Sains dalam kurikulum Program Studi Pendidikan Guru Madrasah Ibtidaiyah (PGMI) masih sebatas pada pemunculan beberapa mata kuliah keislaman dan sains secara terpisah, seperti Studi Islam, Islam dan Ilmu Pengetahuan, Fiqh, Matematika Dasar. Suasana integrasi Islam dan Sains tampak pada tradisi berbusana mahasiswi dan aktifitas perkuliahan yang mengaharuskan seluruh dosen-mahasiswa melakukan tadarrus al-Qur'an di awal perkuliahan.
\end{abstract}

Keyword: integrasi, kurikulum

Pengutipan: Fauzan. (2017). Integrasi Islam dan Sains dalam Kurikulum Program Studi Pendidikan Guru MI Berbasis KKNI. JMIE: Journal of Madrasah Ibtidaiyah Education, 1(1), 2017, 1-13. sd.v1i1.21.

\section{Pendahuluan: Transformasi IAIN menjadi UIN}

Perubahan Instutut Agama Islam Negeri (IAIN) menjadi Universitas Islam Negeri (UIN) Syarif Hidayatullah Jakarta pada tahun 2002 membawa dampak perubahan besar bagi civitas akademika, bukan hanya menyangkut pola perubahan numenklatur, penyebutan nama fakultas, logo, tetapi lebih pada pola pengembangan 
mutu akademik yang juga harus berubah sesuai tuntutan sebuah universitas.

Perubahan LAIN menjadi UIN memberi pengertian bagi kita bahwa perubahan adalah upaya melakukan proses perubahan kurikulum, cara, metodologi, situasai dan kondisi yang tradisional (ortodox) ke arah yang lebih rasional, profesional dan sejalan dengan perkembangan ilmu pengetahuan dan teknologi. Perubahan merupakan tanda dalam kehidupan yang selalu berlangsung secara tetap. Apabila tidak terjadi perubahan, maka akan terjadi kemandegan dan kehidupan tidak akan berkembang sesuai perkembangan zamannnya. Menurut Hussey (2000: 6) ada beberapa faktor mengapa sebuah institusi melakukan sebuah perubahan, yaitu pertama, perubahan ilmu dan teknologi yang terus meningkat; kedua, persaingan semakin intensif dan menjadi lebih global; dan ketiga, tuntutan pelanggan atau masyarakat. (Wibowo, 2007), h. 74)

Jika pada masa IAIN fokus kajian lebih diorientasikan pada kajian ilmu-ilmu agama (religious science), seperti ilmu usul al-din, jinayah siyasah, tafsir hadits, tarbiyah, dakwak; maka di era UIN tidak lagi bicara spesifikasi satu pembidangan ilmu agama keislaman, tetapi cakupan kajian harus lebih luas, umum (universe) dalam pembidangan ilmu pengetahuan. Secara historis, kehadiran IAIN dengan spesisikasi pembidangan ilmu agama Islam tidak terlalu salah, karena sebagai bangsa yang mayoritas muslim sudah seharusnya memiliki kampus Islam yang modern, tidak kumuh, dan lebih terbuka, terutama menyangkut perbedaan pendapat madzhab (fiqih, tasawuf/tariqat). Kehadirannya menjadi transformasi kelembagaan pendidikan pesantren dengan kajian keislaman yang sangat tradisional pola pendidikan keislaman yang sangat modern. Pesantren dengan ciri "nyarung" bertujuan melahirkan ahli-ahli agama Islam (da'i) atau "orang bener" biasanya hanya mengenalkan materi pembelajaran yang sangat dikhotomis, misalnya satu madzhab fiqih (umumnya hanya madzhab Syafi'i), tasawuf akhlaqi, tariqat naqsabandiyah, dengan metode pembelajaran "sorogan" dan "bandongan". Lembaga ini juga tidak memiliki desain kurikulum yang pasti, kurikulum (sebagai materi pelajaran) biasanya identik dengan keahlian kiyai pengasuh, serta tidak memiliki target waktu yang jelas sebagaimana layaknya lembaga pendidikan. Kehadiran IAIN menawarkan warna baru kepada ummat Islam pada saat itu bahwa studi kajian Islam begitu luas dan terbuka dengan berbagai pola pembelajaran baru yang lebih berkualitas, serta kurikulum pembelajaran yang lebih jelas, sistemik, inovatif menyesuaikan dengan tuntutan zaman. Kehadiran IAIN bertujuan "melahirkan ahli-ahli agama dan para pemimpin Islam", belakangan tujuan tersebut mulai diragukan banyak kalangan. Ada tiga fungsi tradisional IAIN, yaitu; pertama, sebagai media

1 Sorogan dan bandongan merupakan dua metode klasik yang ada di pesantren. Sistem sorogan adal sistem membaca kitab secara individul, atau seorang muridnyorog (menghadap guru sendiri-sendiri) untuk dibacakan (diajarkan) oleh gurunya beberapa bagian dari kitab yang dipelajarinya, kemudian sang murid menirukannya berulang kali. Sistem bandungan adalah sistem transfer keilmuan atau proses belajar mengajar yang ada di pesantren salaf di mana kyai atau ustadz membacakan kitab, menerjemah dan menerangkan. Sedangkan santri atau murid mendengarkan, menyimak dan mencatat apa yang disampaikan oleh kyai. 
penyampai pengetahuan agama (transfer of Islamic knowledge), kedua, sebagai media pemelihara tradisi Islam (maintenance of Islamic tradition) dan yang ketiga, sebagai media pencetak ulama (reproduction of ulama). (Jurnal Madrasah, Vol. I, No. 4, 1998, h. 6). Mengapa IAIN (saat itu) tidak diarahkan pada pada pengkajian ilmu yang lebih lebih luas? Mengapa kewenangan yang diberikan IAIN hanya fokus pada study Islam? Kondisi ini menunjukkan bahwa kehadiran IAIN cenderung lebih pada urusan politik pembagian "jatah" kepada ummat Islam sebagai apreasiasinya dalam konteks kemerdekaan Republik Indonesia yang di masa-masa awal terlihat sangat spesifik pada kajian studi Islam dan cenderung masih "memakruhkan" ilmu pengetahuan umum. Padahal jika ditilik dalam sejarah, kejayaan dan keemasan Islam (golden age) pada masa Bani Abbasiyah ((133-766 H/750-1258)) dilihat karena kemajuan peradaban dan ilmu pengetahuan yang begitu luas. Bahkan beberapa ayat al-Quran menjelaskan kata "ilmu" (seperti, al-Baqoroh: 282, 31-32, al-Kahfi: 65, al-Nahl: 8, al-Isro: 85, Fathir: 28, al-Mujadalah: 11) dengan makna yang umum (ilmu agama dan ilmu umum), keberadaanya diakui sebagai posisi sentral dalam pembentukan peradaban, watak, dan perkembangan manusia. Bagi Al-Farabi ilmu (ilm) dipahami sebagai batang tubuh pengetahuan yang terorganisir dan sebagai sebuah disiplin yang mempunyai tujuan, premis dasar, dan objek serta metode penelitian tertentu. (Osman Bakar: 1998, h. 104)

Dalam kesempatan yang lain, perkembangan teknologi informasi, IAIN (sebagai produk perubahan) dinilai lamban, konservatif, statis, cakupan keilmuan yang sempit dan masih belum mampu menyiapkan generasi yang handal dan juga belum siap menghadapi tuntutan zaman. Paradigma dan tujuan IAIN sebagaimana dijelaskan di atas, dewasa ini dianggap kurang relevan lagi dengan perkembangan ilmu pengetahuan dan tuntutan pembangunan nasional, karena bersifat sangat sektoral, hanya memenuhi kebutuhan akan sarjana-sarjana yang mendapatkan pengetahuan tinggi mengenai agama Islam. (Muhaimin, Wacana Pengembangan Pendidikan Islam di Indonesia, (Yogyakarta: 2003), h. 252)

Sementara di era IPTEK yang sarat dengan percepatan informasi, teknlogi menuntut keberadaan perguruan tinggi dapat melahirkan manusia-manusia yang bukan hanya mengusai ilmu pengetahuan secara utuh, kecerdasan, dengan skill professional tetapi bagaiman nilai-nilai positif yang terkandung dalam agama (Islam) tertanam kuat dalam setiap langkah gerak kehidupan.

Seiring dengan perubahan tersebut, UIN (Jakarta) sendiri mencoba merumuskan kembali visi kelembagaannya, yaitu "menjadikan kampus berskala Nasional dan Internasional yang mengintegrasikan ke-Islaman, ke-Ilmuan, keIndonesiaan, dan kemanusiaan". Empat nilai tersebut diharapkan bisa menjadi distingsi dan perbedaan dengan beberapa kampus Islam yang lain. Keislaman seharusnya menjadi brand utama yang ditunjukkan UIN, baik secara kultur, tradisi, perilaku civitas akademika, kurikulum, maupun dalam kegiatan pembelajaran. 
UIN berusaha menjadi kampus yang berusaha mengajarkan kepada masyarakat tentang nilai-nilai keislaman moderat, modern, agama yang memberikan rahmat bagi seluruh alam (rahmatan lil alamin). Oleh karenanya, model Islam demikian, bukan hanya "ajaran" yang diberikan secara tekstual (ayatisasi dalam perkuliahan), tetapi lebih dari itu Islam yang menjadi "nilai" atau perilaku yang tertanam kuat dalam kehidupan. Keilmuan menunjukan bahwa UIN tidak lagi terkungkung oleh dominasi ilmu tertentu dengan target idealis menyiapkan ahli-ahli syurga, tetapi harus lebih terbuka terhadap ilmu pengetahuan sebagai penentu keberhasilan seseorang dalam mengarungi kehidupan di masa mendatang. Dengan konteks keindonesiaan keberadaan UIN diharapkan dapat menjadi corong utama dalam mempertahankan nasionalisme, nilai-nilai Pancasila, kebhinekaan, serta kekhasan budaya Indonesia dengan tetap berusaha mengakomodasi nilai-nilai kemoderanan positif yang berkembang di dunia.

Perspektif integrasi melalui empat nilai tersebut harus dipahami secara utuh dan tidak parsial, implementasinya dilaksanakan secara simultan oleh semua civitas akademika, baik melalui melalui manajemen, kurikulum, maupun kegiatan pemerkuliahan. Oleh karena itu, efektifitas penerapan integrasi keilmuan, keislaman, keindonesiaan, dan kemodernan dapat dilakukan jika seluruh dosen, mahasiswa, tenaga kependidikan di universitas, fakultas, jurusan/program studi memiliki paradigma yang sama dalam menerapkan konsep integrasi keilmuan.

\section{Kurikulum Program Studi}

Ujung tombak pendidikan tinggi terletak pada eksistensi program studi dalam menjalankan berbagai aktifitas akademik/non akademik yang mengarah pada peningkatan mutu lulusan pendidikan. Setiap satuan pendidikan memiliki sistem untuk menghasilkan lulusan yang berkualitas. Sistem pendidikan tinggi di Indonesia memiliki empat tahapan pokok, yaitu (1) Input, (2) Proses; (3) Output, dan (4) Outcomes. Input Perguruan Tinggi (PT) adalah lulusan SMA, MA, dan SMK sederajat yang mendaftarkan diri untuk berpartisipasi mendapatkan pengalaman belajar dalam proses pembelajaran yang telah ditawarkan. Input yang baik memiliki beberapa indikator, antara lain nilai kelulusan yang baik, namun yang lebih penting adalah adanya sikap dan motivasi belajar yang memadai. Kualitas input sangat tergantung pada pengalaman belajar dan capaian pembelajaran calon mahasiswa.

Tahapan selanjutnya adalah menjalani proses pembelajaran. Proses pembelajaran yang baik memiliki unsur yang baik dalam beberapa hal, yaitu: (1) capaian pembelajaran (learning outcomes) yang jelas; (2) Organisasi PT yang sehat; (3) Pengelolaan PT yang transparan dan akuntabel; (4) Ketersediaan rancangan pembelajaran PT dalam bentuk dokumen kurikulum yang jelas dan sesuai kebutuhan pasarkerja; (5) Kemampuan dan ketrampilan SDM akademik dan 
nonakademik yang handal dan profesional; (6) Ketersediaan sarana-prasarana dan fasilitas belajar yang memadai. Dengan memiliki keenam unsur tersebut, PT akan dapat mengem bangkan iklim akademik yang sehat, serta mengarah pada ketercapaian masya rakat akademik yang profesional. Pada perkembangannya, ketercapaian iklim dan masyarakat akademik tersebut dijamin secara internal oleh PT masing-masing. Namun, proses penjaminan kualitas secara internal tersebut hanya dilakukan oleh sebagian kecil PT saja. Oleh karenanya, pemerintah melalui Menteri Pendidikan dan Kebudayaan, mensyaratkan bahwa PT harus melakukan proses penjaminan mutu secara konsisten dan benar agar dapat menghasil kan lulusan yang baik.

Setelah melalui proses pembelajaran yang baik, diharapkan akan dihasilkan lulusan PT yang berkualitas. Beberapa indikator yang sering digunakan untuk menilai keberhasilan lulusan PT adalah (1) IPK; (2) Lama Studi dan (3) Predikat kelulusan yang disandang. Namun proses ini tidak hanya berhenti disini. Untuk dapat mencapai keberhasilan, perguruan tinggi perlu menjamin agar lulusan nya dapat terserap di pasar kerja. Keberhasilan PT untuk dapat mengantarkan lulusannya agar diserap dan diakui oleh pasarkerja dan masyarakat inilah yang akan juga membawa nama dan kepercayaan PT di mata calon pendaftar yang akhirnya bermuara pada peningkatan kualitas dan kuantitas pendaftar (input).

Untuk sampai pada kebutuhan empat hal tersebut diperlukan kerangka konsep yang dapat memayungi semua kegiatan tersebut, mulai dari aspek tujuan, prosese pembelajaran, penyiapan sumber daya manusianya, serta evaluasi selama kegiatan berlangsung. Aspek-aspek itulah yang kemudian dikenal dengan istilah "kurikulum".

Dalam perspektif Pendidikan Tinggi, "kurikulum adalah seperangkat rencana dan pengaturan mengenai capaian pembelajaran lulusan, bahan kajian, proses dan penilaian yang digunakan sebagai pedoman penyelenggaraan program studi." (Permendikbud No. 49 tahun 2014) Kurikulum adalah sebuah program yang disusun dan dilaksanakan untuk mencapai capaian pembelajaran yang diharapkan program studi tertentu. Oleh karenanya, eksistensi sebuah kurikulum pendidikan tinggi sangat terkait langsung dengan aspek tujuan (learning outcome) yang diharapkan, bahan kajian yang disajikan, kegiatan pembelajaran yang dilakukan dosen dan mahasiswa, serta pola penilaian yang menjadi ukuran keberhasilan dari proses pembelajaran yang sedang atau telah selesai dilaksanakan.

Dalam implementasinya, keberadaan kurikulum dapat dibedakan menjadi dua bagian, yaitu 1) dokumen kurikulum (curriculum plan), biasanya dalam bentuk rincian matakuliah, silabus, rancangan pembelajaran, sistem evaluasi keberhasilan. 2) pelaksanan kegiatan pembelajaran yang nyata-nyata dilakukan (actual curriculum). Ini artinya, perubahan sebuah kurikulum harus dimulai dari perubahan dokumen kurikulum yang dibutuhkan, kemudian diiringi dengan perubahan pelaksanaan 
pembelajaran, penciptaan suasana belajar, serta cara evaluasi/asesmen pembelajaran.

Jika perubahan kurikulum tersebut diarahkan pada dokumen dan proses pembelajaran yang dilakukan, hal ini akan mengarah pada cara pandang yang lebih luas tentang kurikulum. Oleh karenanya, kurikulum dapat berperan sebagai: (1) Kebijakan manajemen pendidikan tinggi untuk menentukan arah pendidikannya; (2) Filosofi yang akan mewarnai terbentuknya masyarakat dan iklim akademik; (3) Patron atau Pola Pembelajaran; (4) Atmosfer atau iklim yang terbentuk dari hasil interaksi manajerial PT dalam mencapai tujuan pembelajarannya; (5) Rujukan kualitas dari proses penjaminan mutu; serta (6) Ukuran keberhasilan PT dalam menghasilkan lulusan yang bermanfaat bagi masyarakat. (lihat Buku Panduan Pengembangan KBK, Dikti 2008)

Sejak penerapan kurikulum pendidikan tinggi tahun 2000 dan 2004 (Kurikulum Berbasis Komptensi) posisi dan peran program studi begitu central dalam merancang, mendesain (plan dan actual) kurikulum yang dapat menghasilkan lulusan bermutu dan berdaya saing saing tinggi. Kurikulum tahun 2000 misalnya, menyebutkan bahwa pendidikan tinggi yang menjadi dasar penyelenggaraan program studi terdiri atas harus memuat (1) kurikulum inti dan (2) kurikulum institusional. Kurikulum inti merupakan kelompok bahan kajian dan pelajaran yang harus dicakup dalam suatu program studi yang dirumuskan dalam kurikulum yang berlaku secara nasional. Kurikulum inti terdiri atas kelompok rnatakuliah pengembangan kepribadian (MKK), kelompok mata kuliah yang mencirikan tujuan pendidikan dalam bentuk penciri ilmu pengetahuan dan ketrampilan (MKP), keahlian berkarya, sikap berperilaku dalam berkarya. dan cara berkehidupan bermasyarakat (MKB), sebagai persyaratan minimal yang harus dicapai peserta didik dalam penyelesaian suatu program studi. Sedangkan kurikulum institusional merupakan sejumlah bahan kajian dan pelajaran yang merupakan bagian dan kurikulum pendidikan tinggi, terdiri atas tambahan dan kelompok ilmu dalam kurikulum inti yang disusun dengan memperhatikan keadaan dan kebutuhan lingkungan serta ciri khas perguruan tinggi yang bersangkutan. (Pedoman Penyusunan Kurikulum Pendidikan Tinggi dan Penilaian Hasil Belajar Mahasiswa, Nomor 232/U/2000)

\section{Konsep Integrasi Islam dan Sains}

Sebelum membahas detail tentang konsep integrasi islam dan sains, terlebih dijelaskan tentang perbedaan konsep Islam (sebagai ilmu) dengan ilmu pengetahuan (sains). Dalam The Book of Knowledge, al-Ghazali (450/1058-505/1111) mendifinisikan ilmu agama (al-ulum al-syariah) sebagai ilmu yang diperoleh dari nabi-nabi dan tidak hadir pada mereka melalui akal, seperti aritmatika, atau 
percobaan seperti pengobatan (kedokteran), atau dengan mendengar, seperti bahasa. Sementara ilmu pengetahuan, al-Ghzali menyebutnya dengan istilah ilmu intelektual dipahami sebagai ilmu yang dicapai atau diperoleh melalui intelek manusia semata. ${ }^{2}$ (Osman Bakar: 1998, h. 233) Kedua ilmu tersebut yang ikut mewarnai perjalanan dan kejayaan ummat Islam pada abad keemasa.

Gagasan mengenai "sains Islami” atau "Islamisasi sains" merupakan reaksi atas sains modern yang ateistik-materialistik tersebut. "Sains Islami” ini pada mulanya dipopulerkan oleh para pemikir muslim seperti Sayyed Hossein Nasr, Ziauddun Sardar, Ismail al-Faruqi, al-Attas dan akhir-akhir ini Mehdi Golshani. Walaupun ada perbedaan dalam pola pemetaan konsep tentang islamisasi ilmu pengetahuan yang ditawarkan kedua tokoh tersebut, tapi ruh yang ditawarkan tentang islamisasi ilmu pengetahuan kedua tokoh tersebut sama, yakni bagaimana penerapan ilmu pengetahuan sebagai basis kemajuan umat manusia tidak dilepaskan dari aspek sipritual yang berlandaskan pada sisi normatif al-Qur'an dan al-Sunah. Sebaliknya, memahami nilai-nilai kewahyuan, umat Islam harus memanfaatkan ilmu pengetahuan. Pemikiran mereka kerap kali dilabeli dengan "islamisasi ilmu". Meskipun gagasan mereka berebeda, semuanya bergerak pada lapangan dan tingkat yang sama yaitu tingkat epistemologi dan sedikit menyentuh aspek metafisika.

Istilah integrasi Islam dan Sains dipahami sebagai upaya mempertemukan, memadukan atau menjalin kemitraan antara ilmu dan agama dalam upaya mensejajarkan ilmu dan agama. Konsep tersebut mencoba memberikan porsi yang sama antara sains atau ilmu dengan agama Islam dengan berlandaskan nilainilai universalitas Islam, yaitu bersumber pada ayat qauliyah (baca: al-Qur'an dan hadis) serta ayat kauniyah (fenomena alam). Perpaduan antara urusan duniawi dan ukhrowi, jasmani dan rohani, material dan spiritual menjadi satu kesatuan yang sama-sama bersumber dari Tuhan.

Tujuan utama universitas Islam seharusnya membangun suatu landasan yang komprehensif bagi rekonstruksi peradaban Muslim. Sebagai institusi yang menyediakan landasan pengetahuan bagi peradaban Muslim, universitas Islam harus tanggap mencermati setiap kebutuhan masyarakat Muslim yang berubah dari masa ke masa. Sebuah universitas Islam haruslah mampu menawarkan dan mengembangkan program studi keilmuan secara luas yang mencakup ilmu-ilmu keislaman, baik yang berkaitan langsung dengan penerapan aktivitas keagamaan, maupun ilmu-ilmu pendukung aktivitas pendukung keagamaan itu. Kedua ranah

2 Menurut al-Ghazali, dilihat dari klasifikasinya ilmu dapat dibedakan menjadi dua, yaitu ilmu agama (ilmu syar'i) dan ilmu intelektual. Ilmu Agama terdiri dari (1) ilmu prinsip-prinsip dasar (al-Ushul) yang bersifat fardhu ain, a) ilmu keesaan ilahi (al-tauhid), b) ilmu kenabian, c) ilmu akhirat dan eskatologi, d) ilmu sumber pengetahuan religiuos (al-Quran fan as-Sunah); (2) ilmu cabang-cabang (furu') antara lain: ilmu kewajiban manusia kepada Tuhan dan ilmu kewajiban manusia kepada masyarakat. Sementara ilmu pengetahuan (intelektual) terdiri dari Matematika, aritmatika, geometri, astronomi dan astrologi, musik, logika, fisika atau ilmu alam, kedokteran, meteorologi, minerologi, kimia. (Osman Bakar: h. 235-236) 
keilmuan ini kini harus dipandang secara integral, holistik dan komplementer berlandaskan worldview Islam tentang taubid.

Munculnya fenomena integrasi dengan berbagai konsep yang ditawarkan dimulai sejak abad kemunduran Islam (abad ke-12 M), para penguasa muslim kurang memberikan penghargaan terhadap ilmu pengetahuan hingga akhir abad ke-16 di mana mulai terputus hubungan antara dunia Islam dengan aliran utama dalam sains dan teknologi. Pada saat itu, umat Islam sangat tertinggal jauh dibanding masyarakat Barat dalam ilmu pengetahuan. Di sisi lain, para ulama, sebagaimana dikatakan Aziz (1993: 3) juga sangat inward looking dalam memahami ilmu-ilmu agama. Ketertinggalan dalam memahami wahyu ini sampai mencapai tingkat kebenaran yang tidak memadai, diasumsikan karena tertinggal dalam penguasaannya terhadap ilmu-ilmu pengetahuan umum (Mudjia Rahardjo, 2002: 241).

Selain masalah ketertinggalan dalam penguasaan ilmu pengetahuan, hal terbesar yang dihadapi umat Islam dewasa ini adalah berkaitan paradigma berpikir. Umat Islam masih berpikir secara tradisional, masih ada sebagian umat Islam yang memandang ayat/surat dalam Al-Qur'an hanya dari sisi mistik, bukan justru memahami, mengembangkan wacana-wacana keimananan, kemanusiaan dan pengetahuan yang terkandung di dalamnya. Ini jelas menunjukkan sebuah pola berpikir partikularistik dan ritualistik yang tidak sejalan dengan ruh Islam itu sendiri. Memang tidak salah cara berpikir demikian Namun bila hal itu terlalu dikedepankan, maka Al-Qur'an sebagaimana diyakini Fazlurrahman sebagai sumber ilmu pengetahuan, hanya akan menjadi saksi sejarah kemunduran Islam. Padahal, Al-Qur'an sarat dengan nilai-nilai keimanan, kemanusiaan, peradaban dan ilmu pengetahuan.

Dari definisi islamisasi pengetahuan di atas, ada beberapa model islamisasi pengetahuan yang bisa dikembangkan dalam menatap era globalisasi, antara lain: model purifikasi, model modernisasi Islam, dan model neo-modernisme. Dengan melihat berbagai pendekatan yang dipakai Al-Faruqi dan Al-Attas dalam gagasan Islamisasi Ilmu Pengetahuan, seperti: 1) Penguasaan khazanah ilmu pengetahuan muslim; 2) Penguasaan khazanah ilmu pengetahuan masa kini; 3) identifikasi kekurangan-kekurangan ilmu pengetahuan itu dalam hubungannya dengan ideal Islam; dan 4) Rekonstruksi ilmu-ilmu itu sehingga menjadi paduan yang selaras dengan warisan dan idelitas Islam, maka gagasan Islamisasi keduanya dapat dikategorikan ke dalam model purifikasi ini (Muhaimin, 2002: 234). Sedangkan model neo-modernisme berusaha memahami ajaran-ajaran dan nilai-nilai mendasar yang terkandung dalam Al-Qur'an dan sunnah dengan mempertimbangkan khazanah intelektual muslim klasik serta mencermati kesulitan-kesulitan dan kemudahan-kemudahan yang ditawarkan oleh dunia IPTEK.

Dalam kontek pendidikan, demi pemenuhan hajat integrasi mutlak diperlukan 
sistem integrasi kurikulum (integrated curriculum), satu konsep perpaduan beragam macam keilmuan tanpa melihat batas perbedaan, meniadakan batas antara mata kuliah dan menyajikan bahan ajar dalam bentuk keseluruhan antara ilmu duniawi dan ilmu ukbrowi. Dengan meniadakan batas tersebut diharapkan dapat menjadikan para mahasiswa menjadi pribadi yang integrated, utuh antara penguasaan keilmuan sebagai tuntutan zaman dengan kemampuan aplikatif beragama yang sangat baik.

Integrated curriculum berusaha memadukan mata kuliah umum dan keislaman menjadi satu kesatuan yang tidak dapat dipisahkan, sehingga dalam pelaksanaannya dosen mata kuliah umum harus mengetahui ilmu agama, nilai-nilai dan perilaku kegamaan yang dapat diintegrasikan dalam proses pembelajaran (Turmudzi: 2006, h. 35). Sementara pengampu mata kuliah agama juga berusaha mengaitkan materi yang disampaikan dengan tidak melupakan sama sekali perkembangan IPTEK. Integrasi Islam dalam mata kuliah umum dapat dilakukan melalui tiga cara, yaitu (1) secara konvensional dapat dilakukan dengan mencarikan argumentasi doktrinal (ayatisasi) berupa ayat-ayat al-Quran yang relevan. Hanya saja dalam implementasinya menjadi persoalan tersendiri jika semua sajian ilmu harus dicarikan ayat yang terkait, tidak semua ilmu pengetahuan terbahas dalam al-Quran. Sebagai sebuah pedoman, al-Quran berisi sebuah ajaran, aturan, petunjuk tentang berbagai hal (termasuk fenomena alam), akan tetapi tidak membehas secara teknis operasional seperti layaknya buku ilmu pengetahuan; (2) implementasi integrasi juga dapat dilakukan dengan melakukan pembaiasaan tadarrus al-Quran di setiap awal atau akhir perkuliahan. Cara ini dilakukan untuk mendekatkan para mahasiswa kepada al-Quran, dan mengingatkan mereka betapa tidak memiliki nilai kemanfaatan yang besar manakala jauh dari nilai-nilai ilahiyah; (3) integrasi dapat dilakukan melalui penerapan nilai-nilai, perilaku, akhlak yang diajarkan Islam, seperti kedesiplinan, tanggung jawab, jujur, dan tanggung jawab. Keempat nilai tersebut yang disinyalir sebagai orang sebagai akibat dari kemunduran Islam saat ini. Oleh karenanya, melalui penerapan nilai-nilai keislaman dalam perkuliahan menjadi alternatif solusi efektifitas penerapan integrasi illmu pengetahuan dengan Islam.

\section{Dilema Prodi PGMI: Antara Dominasi Agama dan Sains}

Keberadaan kurikulum dalam pendidikan tinggi sangat sentral, karena beberapa alasan sebagai berikut: 1) Sumber kebijakan manajemen pendidikan tinggi untuk menentukan arah penyelenggaraan pendidikannya; (2) Filosofi yang akan mewarnai terbentuknya masyarakat dan iklim akademik; (3) Patron atau pola pembelajaran, yang mencerminkan bahan kajian, cara penyampaian dan penilaian pembelajaran; (4) Atmosfer atau iklim yang terbentuk dari hasil interaksi manajerial PT dalam mencapai tujuan pembelajarannya; (5) Rujukan kualitas dari proses penjaminan mutu; serta (6) ukuran keberhasilan PT dalam menghasilkan lulusan yang bermanfaat bagi masyarakat. Dari penjelasan ini, nampak bahwa kurikulum 
tidak hanya berarti sebagai suatu dokumen saja, namun merupakan suatu rangkaian proses yang sangat krusial dalam pendidikan. (Kurikulum Pendidikan Tinggi: 2014, h. 7) Posisi kurikulum menjadi begitu penting dan strategis dalam konteks peningkatan mutu pendidikan tinggi. Upaya perbaikan, perubahan, pengembangan kurikulum berdasarkan kebutuhan masyarakat luas, perkembangan IPTEK menjadi sebuah keharusan.

Dalam konteks Program studi Pendidikan Guru MI, desain kurikulum telah mengalami beberapa perubahan. Pertama, tahun 2011 disebut sebagai tahun "perombakan", pengurangan, bahkan penggabungan (merger) mata kuliah karena dianggap duplikasi atau saling berbenturan satu sama lain. Hasil temuan yang dilakukan Tim Melborn Australia, menjelaskan bahwa kurikulum PGMI tergolong masih "padat mata kuliah", bahkan keberadaan mata kuliah yang diajarkan masih duplikasi antara satu mata kuliah dengan mata kuliah yang lain. Arah pengembangan kurikulum juga masih belum jelas antara penyiapan "ahli agama" (guru agama) atau "guru kelas" sebagaimana tujuan awal didirikannya. Ketidakpamahan masyarakat dan dukungan kebijakan pemerintah (Kementerian Agama dan Kemendikbud) yang terbelah berdampak pada penunjukan image masyarakat yang begitu jika PGMI merupakan bagian dari prodi yang akan melahirkan calon guru agama. Kondisi ini terus diperparah oleh adanya sistem kurikulum PGMI dengan dominasi mata kuliah Pendidikan Agama Islam (PAI), penulis sering menyebutnya dengan "kurikulum PGMI rasa PAI". Wujud kurikulum pada masa awal itu jelas keliru, karena tidak sesuai pencapaian kompetensi sebagai Guru Kelas MI, yakni penguasaan kemampuan pedagogik dan konten pada lima mapel MI, Matematika, IPA , IPS, PKn, dan Bahasa Indonesia tingkat MI.

Kedua, perubahan kurikulum dilakukan pada tahun 2013. Arah dari perubahan kurikulum Prodi PGMI saat itu difokuskan pada upaya mengakomodasi dua kebijakan yang sudah ditetapkan, yaitu kebijakan tentang Kerangkan Kualifikasi Nasional Indonesia (KKNI), dan kebijakan implementasi kurikulum 2013. Pergeseran wacana penamaan kurikulum pendidikan tinggi dari KBK (Kurikulum Berbasis Kompetensi) ke penamaan Kurikulum Pendidikan Tinggi memiliki beberapa alasan yang penting, (Panduan Kurikulum Pendidikan Tinggi: 2014, h. 12-13) diantaranya:

1. Penamaan KBK tidak sepenuhnya didasari oleh ketetapan peraturan, sehingga masih memungkinkan untuk terus berkembang.

2. KBK mendasarkan pengembangannya pada kesepakatan penyusunan kompetensi lulusan oleh perwakilan penyelenggara program studi yang akan disusun kurikulumnya.

3. Ketiadaan parameter ukur dalam sistem KBK menjadikan sulit untuk menilai apakah program studi jenjang pendidikan yang satu lebih tinggi atau lebih rendah dari yang lain. 
4. Kerangka Kualifikasi Nasional Indonesia (KKNI) memberikan parameter ukur berupa jenjang kualifikasi dari jenjang 1 terendah sampai jenjang 9 tertinggi.

5. CP pada setiap level KKNI diuraikan dalam diskripsi sikap dan tata nilai, kemampuan, pengetahuan, tanggung jawab dan hak dengan pernyataan yang ringkas yang disebut dengan deskriptor generik.

6. K-DIKTI sebagai bentuk pengembangan dari KBK menggunakan level kualifikasi KKNI sebagai pengukur CP sebagai bahan penyusun kurikulum suatu program studi. g) Perbedaan utama K-DIKTI dengan KBK dengan demikian adalah pada kepastian dari jenjang program studi karena CP yang diperoleh memiliki ukuran yang pasti.

Apakah perubahan kurikulum prodi PGMI sudah mempertimbangkanintegrasi Islam dan Ilmu Pengetahuan? Beberapa perubahan kurikulum Prodi PGMI masih bersifat parsial dan belum terintegrasi dengan visi universitas. Integrasi Islam, keilmuan, keindonesiaan, kemoderanan sebagaimana yang gaungkan sejak tahun 2002 kurang begitu terlihat, terutama menyangkut hal-hal yang bersifat substanstif. Pola integrasi hanya terlihat hanya pada pembagian mata kuliah antara ilmu umum dan ilmu keislaman. Misalnya, kurikulum 2007 sebagaimana dijelaskan di atas ada sejumlah mata kuliah agama Islam, seperti Al-Quran Hadits, Akhlak Tasawuf, Akidah Akhlak, Tafsir, Fiqh, Sejarah Kebudayaan Islam, Studi Islam lengkap dengan desain pembelajarannya masing-masing, sehingga pada kurikulum dekade ini susah membedakan antara PGMI dan PAI. Tetapi pada sisi lain, prodi PGMI menawarkan sejumlah mata kuliah dari rumpun bidang keilmuan bahasa, IPA, IPS, PKn, dan Matematika. Hanya saja porsi mata kuliah belum memenuhi kebutuhan kompetensi guru kelas.

Ada perbedaan sedikit pada kurikulum 2011, porsi kurikulum sudah disesuaikan dengan pemenuhan kebutuhan sebagai guru kelas. Alhasil, kurikulum yang ditawarkan sudah diarahkan pada kompetensi guru kelas, dengan memadukan beberapa kelompok mata kuliah umum (mapel umum) dan kelompok mata kuliah keislaman. Ada berkelompok keilmuan yang menjadi target pencapaian kompetensi guru kelas, yaitu 1. Kelompok mata kuliah Bahasa Indonesia, terdiri dari Apresiaisi Bahasa dan Sastera Indonesia, Ketrampilan Berhasa Indonesia; 2) kelompok mata kuliah, terdiri dari konsep dasar sains, pembelajaran IPA, Gizi dan Makanan, Pendidikan lingkungan, Kapita Selekta IPA; 3) kelompok mata kuliah Matematika, terdiri atas Matematika Dasar, Geometri, Aljabar, Peluang dan statistika, pembelajaran matematika; 4) kelompok mata kuliah IPS/PKn terdiri atas Pendidikan Kewarganegaraan, konsep dasar IPS, Pembejalaran IPS/PKn, Sejarah Indonesia, Sejarah Dunia, Pancasila, Nasionalisme dan globalisasi. Ada sejumlah kelompok mata keislaman yang ditawarkan, antara lain Fiqh, Akidah 
SD, al-Quran Hadis, SKI, dan pembelajaran PAI, porsi sks untuk kelompok mata kuliah keislaman sangat sedikit, hanya sebagai penciri dan pembeda dengan Prodi Pendidikan Guru SD.

Dengan demikian pola integrasi konvesional pada prodi PGMI sesungguhnya sudah dilakukan, walaupun belum mengarah pada implementasi integrasi yang sesungguhnya. Kebijakan Hingga saat ini, program studi belum punya kebijakan untuk mengkoneksikan mata kuliah satu dengan yang lain, dengan melibatkan beberapa dosen keilmuan yang berbeda. Masih belum terlihat juga kebijakan yang terkait keharusan mahasiswa untuk menulis skripsi (termasuk pengajuan judul) dengan mengedepankan pola integrasi keilmuan dan keislaman. Kebijakan yang sudah diambil prodi dalam rangka implementasi integrasi islam dan sains masih sangat terbatas, yaitu: pertama, edaran program studi kepada seluruh mahasiswa dan dosen untuk melakukan tadarus al-Quran (khusu juz ke 30) lima menit sebelum perkuliahan dimulai. Kedua, edaran program studi terkait pembiasan berbusana layaknya guru. Seluruh mahasiswa dihimbau untuk senantiasa memakai busan yang sopan, baik, sesuai aturan.

\section{Penutup}

Integrasi Islam dan sains bukanlah sebuah konsep semata, tetapi cita-cita luhur bersama seluruh civitas akademika yang harus dilaksanakan dalam action nyata. Implementasi integrasi Islam dan sains hanya dapat dilakukan melalui perpaduan kurikulum yang dilakukan secara integrated oleh seluruh tenaga pendidik dengan sejumlah kemampuan keilmuan yang tidak lagi parsial. Tuntutan dosen umum mengerti ilmu agama, sebaliknya dosen agama harus memahami konteks perkembangan IPTEK juga menjadi persyaratan mutlak sebuah integrasi dapat diwujudkan di perguruan tinggi. Hal lain yang memiliki andil besar dalam konteks implementasi integrasi Islam dan sain juga harus didukung oleh keberadaan sebuah asrama sebagai lingkungan yang secara efektif akan membentuk warna karakter dari seluruh mahasiswa yang ada. Semoga saja integrasi Islam dan sains tidak hanya berhenti pada tataran konsep, tetapi dapat dilaksanakan kehidupan yang lebih riil. Wallabu 'alam

\section{Daftar Pustaka}

Abuddin Nata, dkk. Integrasi Keilmuan, (Jakarta: RajaGrafindo Persada, 2003). Azyumardi Azra, Membangun Integrasi Ilmu, Iman, Amal, dan Akblak, dalam Proses Perubahan LAIN menjadi UIN, Rekaman Media Massa, (Jakarta: UIN Jakarta Press, 2002),

Abdul Rahman Saleh, Konsepsi dan Pengantar Dasar Pembaharuan Pendidikan Islam, 
(Jakarta: DPP GUPPI, 1993)

Gae Eaton, Islam dan Taqdir Manusia, Jakarta: Suluh press: 2006

Kusmana (ed.), Intergarsi Keilmuan: UIN Syarif Hidayatullah Jakarta, (Jakarta: PIC UIN Jakarta Press, 2007)

Muhaimin, Wacana Pengembangan Pendidikan Islam di Indonesia, (Yogyakarta: 2003)

Mulyadi Kartanegara, Intergarsi Ilmu sebuah Rekonstruksi Holistik, (Bandung: Mizan, 2005)

Direktorat Jenderal Pendidikan Tinggi Kemendikbud RI, Panduan Kurikulum Pendidikan Tinggi: 2014

Quraish Shihab, Wasawasan al-Qur'an, (Bandung: Mizan, 1994)

Osman Bakar, Hierarki Ilmu: Membangun Rangka Pikir Islamisasi Ilmu, Bandung: Mizan: 1998

Umar A Jenie, Arah Prospek Pengembangan Universitas Islam Negeri di Indonesia, Makalah disampaikan pada acara Dies Natalis ke 45 dan Lustrum IX IAIN Syarif Hidayatullah Jakarta, 08 Juni 2002

Turmudzi, Islam, Sains dan Teknologi, UIN Malang Press, 2006

Wibowo, Manajemen Perubahan, (Jakarta: RajaGrafindo Persada, 2007) 